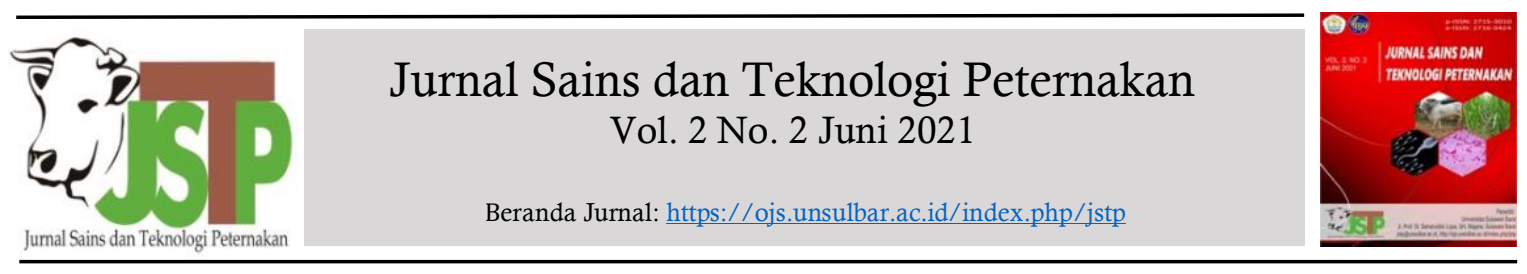

\title{
Respon Pertumbuhan Rumput Setaria (Setaria sphacelata) yang Diberikan Pupuk Kotoran Satwa Kuskus asal Penangkaran
}

(Growth Response of Setaria Grass (Setaria sphacelata) Base on Cuscus Manure Fertilizer from the Animal Captivity)

\author{
Frederik R.S. Mauri ${ }^{1}$, Diana Sawen ${ }^{1 *}$, Alnita Baaka ${ }^{1}$ \\ ${ }^{1}$ Fakultas Peternakan, Universitas Papua, J1. Gunung Salju, Amban, Manokwari, Papua Barat, 98314.
}

\section{A R T I C L E I N F O}

Received: 2 Mei 2021

Accepted: 16 Juni 2021

*Corresponding author sawedian@yahoo.com

Keywords:

Cuscus manur fertilizer

Growth

Setaria grass

Kata Kunci:

Pupuk kotoran kuskus

Pertumbuhan

Rumput Setaria

\section{A B S T R A C T}

Cuscus is an arboreal animal whose habitat is in the forest with the type of food consumed are fruits, leaf shoots, and agricultural plants. Animal manure can also be used as organic fertilizer for forage plants. This study aims to determine the growth response of Setaria grass (Setaria sphacelata) given a dose of cuscus manure fertilizer with banana and avocado consumption. The study was designed in a CRD with 3 treatments. The treatments were P0 = without fertilizer $(100 \%$ soil $), \mathrm{P} 1=40 \mathrm{~g} /$ polybag of cuscus manure with banana consumption, and P2 $=40 \mathrm{~g} /$ polybag of cuscus manure with avocado consumption. Planting is done by pols on polybags measuring $30 \times 25 \mathrm{~cm}$. The results showed that the highest plant height of Setaria grass was found in P2 with an average of 101.70, then $\mathrm{P} 1$ was 101.47 and $\mathrm{P} 0$ was $71.16 \mathrm{~cm} /$ week. The results were the same for the number of leaves and tillers, P2 showed significantly higher results $(\mathrm{P}<0.05)$, followed by $\mathrm{P} 1$ and control. The application of organic fertilizer of cuscus manure with the consumption of bananas and avocados can increase the growth of Setaria grass.

\section{A B S T R A K}

Kuskus merupakan satwa arboreal yang habitatnya di hutan dengan jenis konsumsi pakan berupa buah-buahan, pucuk daun dan tanaman pertanian. Kotoran satwa dapat juga digunakan sebagai pupuk organik untuk tanaman pakan. Penelitian ini bertujuan untuk mengetahui respon pertumbuhan rumput Setaria (Setaria sphacelata) yang diberi dosis pupuk organik kotoran kuskus dengan konsumsi pisang dan avokad. Penelitian didesain dalam Rancangan Acak Lengkap (RAL) dengan 3 perlakuan dan 5 ulangan. Perlakuannya adalah P0 = tanpa pupuk (100\% tanah), P1 $=40 \mathrm{~g} /$ polybag kotoran kuskus dengan konsumsi pisang, dan P2 $=40$ g/polybag kotoran kuskus dengan konsumsi avokad. Penanaman dilakukan dengan pols pada polybag berukuran $30 \mathrm{~cm} \times 25 \mathrm{~cm}$. Hasil penelitian menunjukkan bahwa tinggi tanaman rumput Setaria tertinggi terdapat pada perlakuan P2 dengan rataan 101,70 cm/minggu, selanjutnya P1 sebesar 101,47 cm/minggu dan P0 yaitu 71,16 $\mathrm{cm} /$ minggu. Hasil yang sama juga pada jumlah daun dan jumlah anakan, perlakuan P2 memperlihatkan hasil yang nyata lebih tinggi $(\mathrm{P}<0,05)$, diikuti perlakuan $\mathrm{P} 1(\mathrm{P}<0,05)$ dan kontrol. Namun antara perlakuan $\mathrm{P} 1$ dan P2 tidak berbeda. Pemberian pupuk organik kotoran kuskus dengan konsumsi pisang dan avokad dapat meningkatkan pertumbuhan rumput Setaria. 


\section{Pendahuluan}

Rumput Setaria (Setaria sphacelata) merupakan salah satu spesies hijauan makanan ternak yang sudah banyak dikembangkan di Indonesia. Produktivitas hijauan pakan yang baik perlu memperhatikan kualitas, kuantitas dan kontinuitas ketersediaannya sepanjang tahun, yang sudah tentu berkorelasi dengan produktivitas ternak. Khusus wilayah Papua, jenis rumput Setaria belum banyak dikembangkan atau dibudidayakan secara luas oleh peternak. Ada peternak yang sudah mengembangkan rumput Setaria namun dalam jumlah yang sangat terbatas, hanya untuk kebutuhan ternak yang dimiliki.

Rumput Setaria memiliki kualitas yang baik sebagai hijauan pakan ternak, hal ini dapat dilihat dari pertumbuhan, produksi, maupun nilai nutrisinya serta disukai ternak (palatable). Nilai gizi Setaria sphacelata yaitu protein kasar 6 $7 \%$, serat kasar 42,0\%, Bahan Ekstrak Tanpa Nitrogen (BETN) 36,1 \% dan lemak 2,8\%. Rumput Setaria, disamping sebagai rumput potong untuk pakan, juga digunakan sebagai rumput untuk padang penggembalaan, karena tahan injakan (Prawiradiputra, Sajimin, \& Purwantari, 2006).

Karakteristik lainnya yaitu memiliki daya adaptasi yang tinggi terhadap tanah asam dengan kesuburan rendah, salinitas, iklim, tahan genangan air dan kekeringan (Sawen \& Nuhuyanan, 2020). Rumput ini tergolong rumput potong atau juga rumput padangan dan dapat diolah menjadi silase, hay atau amoniase. Rumput Setaria juga dimanfaatkan sebagai mulsa tanah, juga digunakan sebagai pencegah erosi.

Peningkatan produktivitas hijauan pakan dapat dilakukan dengan pemberian perlakuan pupuk pada media tanam atau lahan, dengan tujuan untuk meningkatkan nilai gizinya. Pupuk organik (PO) yang umum digunakan adalah pupuk yang berasal dari kotoran ternak seperti sapi, kambing, ayam dan juga biourine (Irfan, Rasdiansyah, \& Munadi, 2017). Hasil penelitian Niknik, Marzuki, \& Sugiyanto (2014), yang dilakukan dengan memanfaatkan kotoran ayam petelur berhasil meningkatkan nilai nutrisi rumput Setaria yaitu dari dosis yang sama untuk pupuk organik sebesar $150 \mathrm{~g} /$ pot (15 kg tanah) dan kandungan PK 8,3 \% naik menjadi 12,63\% untuk PO kotoran ayam dan $12,18 \%$ untuk PO kotoran sapi. Kotoran satwa yang biasanya dimanfaatkan sebagai pupuk adalah goano dari kelelawar, dan satwa lainnya pada penangkaran. Satwa penangkaran yaitu Kuskus (Family:
Phalangaridae) dapat juga dimanfaatkan feses atau kotorannya sebagai pupuk organik.

Kuskus tergolong satwa Marsupial (mamalia berkantung) yang habitatnya di hutan pada pohon-pohon sehingga disebut juga satwa arboreal. Jenis pakan yang dikonsumsi oleh kuskus yaitu buah-buahan, pucuk dan dedaunan pohon di hutan serta tanaman pertanian (Sawen \& Sinery, 2020). Secara tidak langsung, pakan yang dikonsumsi mempengaruhi proses metabolisme di dalam tubuhnya dan sekaligus juga mempengaruhi kotoran yang dihasilkan. Faktanya, ketika kuskus diberikan pakan buah pisang matang dan avokad sebagai pakan tunggal, memperlihatkan konsistensi kotoran yang berbeda. Hasil-hasil penelitian tentang jenis pakan kuskus di berbagai daerah di wilayah Papua (Gunung Meja Manokwari, Napan Weinami Nabire, Biak Numfor, dan Jayapura) sudah banyak dilakukan dan terdokumentasi sebagai data base untuk tujuan konservasi dan edukasi, sebagaimana dipelihara di dalam penangkaran. Namun sejauh ini, pemanfaatan kotorannya sebagai pupuk organik belum pernah dilakukan, dengan demikian penelitan ini dilakukan untuk mengetahui sejauh mana pupuk kotoran satwa kuskus mempengaruhi pertumbuhan rumput Setaria.

\section{Materi dan Metode}

\subsection{Tempat dan Waktu Penelitian}

Penelitian dilaksanakan di Taman Ternak Fakultas Peternakan, Fakultas Peternakan, Universitas Papua (UNIPA), Manokwari, selama 2 bulan yaitu bulan Januari sampai dengan Februari 2020.

\subsection{Materi Penelitian}

Materi penelitian antara lain: pols rumput Setaria (Setaria sphacelata), tanah, kotoran satwa kuskus yang berasal dari konsumsi pakan yang berbeda yaitu buah pisang dan avokad, serta air minum. Jenis tanah yang digunakan adalah alluvial yang berasal dari lokasi tersebut. Alat yang digunakan yaitu cangkul, parang/arit, cutter, meteran ukuran $30 \mathrm{~m}$, pita ukur ukuran $100 \mathrm{~cm}$, penggaris ukuran $100 \mathrm{~cm}$, ember, ayakan tanah ukuran 0,5 $\mathrm{mm}$ (35 mesh), timbangan digital kapasitas $100 \mathrm{~g}$ dan $5 \mathrm{~kg}$, karung, tali rapia, kamera, gunting stek, thermohigrometer, polybag ukuran $30 \mathrm{~cm} \times 25 \mathrm{~cm}$, dan alat tulis.

\subsection{Rancangan Percobaan}

Penelitian ini didesain dalam Rancangan Acak Lengkap (RAL) dengan 3 perlakuan dan 5 
ulangan. Perlakuan dalam penelitian ini adalah: $\mathrm{P} 0=$ Kontrol; $\mathrm{P} 1=$ Kotoran kuskus dari konsumsi pisang, dan P2 = Kotoran kuskus dari konsumsi avokad. Buah pisang dan avokad yang digunakan karena merupakan pakan yang dikonsumsi kuskus di habitatnya.

\subsection{Prosedur Penelitian}

\section{Persiapan Media Tanam}

Media tanam yang digunakan adalah tanah. Tanah yang sudah diambil, dibersihkan dari sisasisa ranting kayu, ampas dedaunan kering dan batu, lalu disaring dengan ayakan tanah dari kawat berukuran 0,5 mm (35 mesh) supaya halus. Selanjutnya dijemur selama 1 minggu di atas karung terbuka di bawah matahari agar steril dan siap digunakan. Media tanam (tanah) ditimbang sebanyak $5 \mathrm{~kg}$, dimasukkan masingmasing ke dalam polybag. Kemudian untuk perlakuan P1 dan P2, tanah pada masing-masing polybag dicampurkan dengan pupuk kotoran satwa kuskus sesuai perlakuan dengan perbandingan 1:1 (v/v) (Hadisuwito, 2012). Dosis pemberian pupuk kotoran kuskus adalah $40 \mathrm{~g} /$ polybag, didasarkan pada kebutuhan pupuk organik untuk rumput sebesar 20 ton/ha.

Persiapan Bahan Tanam dan Pupuk Kotoran Kuskus

Pols rumput Setaria yang sudah tua dipotong ukuran $15 \mathrm{~cm}$ dengan menggunakan gunting sebanyak 15 pols sesuai satuan percobahan. Jarak tanam antar polybag adalah $50 \mathrm{~cm}$. Pupuk kotoran kuskus yang digunakan merupakan kotoran segar yang dikumpulkan setiap dua hari sekali selama 3 minggu, dijemur hingga kering dan digiling halus dalam bentuk bubuk. Selanjutnya, ditimbang masing-masing sebanyak $40 \mathrm{~g} /$ polybag sesuai perlakuan P1 dan $\mathrm{P} 2$. Setelah polybag yang berisi tanah sudah siap, masing-masing dicampur dengan pupuk organik kotoran kuskus di atas wadah karung plastik dan dimasukan kembali ke dalam polybag dicampur hingga homogen dan diberi label. Polybag ditempatkan atau diatur sesuai denah penempatan perlakuan.

\section{Penanaman dan Penyeragaman/Trimming}

Pols rumput Setaria ditanam dengan kedalaman $5 \mathrm{~cm}$ di dalam polybag setelah semua polybag sudah siap. Penyeragaman pertumbuhan rumput Setaria dilakukan setelah tanaman berumur 2 minggu, yang dilakukan dengan defoliasi seluruh tanaman yang ada, dengan jarak $15 \mathrm{~cm}$ di atas permukaan tanah.
Tujuan pemotongannya untuk merangsang pertumbuhan kembali anakan dan menyeragamkan pertumbuhan di periode berikutnya (Lakitan, 2007).

\section{Pemeliharaan dan Pengamatan}

Penyiraman secara rutin dilakukan setiap hari, yaitu pagi hari pukul 08.00 dan sore hari pukul 17.00. Frekuensi penyiraman disesuaikan dengan kondisi cuaca dan dilakukan sesuai dengan kapasitas lapang. Penyiangan dilakukan setiap minggu, untuk membersihkan gulma dalam polybag.

Pengamatan dilakukan setiap minggu pada setiap satuan percobaan/polybag. Pengamatan yang dilakukan meliputi: pengukuran tinggi tanaman, jumlah daun, jumlah anakan yang dilakukan selama 6 minggu. Selain itu, dilakukan pengamatan suhu dan kelembaban setiap hari di areal/lokasi penelitian, selama penelitian berlangsung. Data penunjang lainnya yaitu: analisis tanah sebelum dan sesudah penelitian di Balai Penelitian Tanah Bogor dan data suhu dan kelembaban dari Stasiun BMKG Kabupaten Manokwari selama penelitian.

\section{Pemanenan/Defoliasi}

Pemanenan dilakukan setelah rumput Setaria berumur 40 hari, setelah trimming, dengan pertimbangan umur terbaik sebelum masa generative/berbunga. Jarak potong $15 \mathrm{~cm}$ dari permukaan tanah. Rumput segar yang dipotong dari masing-masing polybag ditimbang per rumpun tanaman dengan menggunakan timbangan digital kapasitas $5 \mathrm{~kg}$.

\subsection{Analisis Data}

Data hasil pengamatan yang diperoleh dianalisis menggunakan analisis ragam (Anova) sesuai Rancangan Acak Lengkap (RAL) menggunakan software statistik SPSS versi 22. Perlakuan yang memperlihatkan pengaruh nyata $(\mathrm{P}<0,05)$ dilakukan uji lanjut Duncan Multiple Range Test (DMRT) (Steel \& Torrie, 1993).

\section{Hasil dan Pembahasan}

Hasil rataan tinggi tanaman, jumlah anakan, dan jumlah daun rumput Setaria yang diberikan pupuk kotoran kuskus disajikan pada Tabel 1. Hasil sidik ragam memperlihatkan bahwa perlakuan pemberian pupuk organik kotoran kuskus memberikan pengaruh nyata $(\mathrm{P}<0,05)$ terhadap tinggi tanaman, jumlah daun dan jumlah anakan rumput Setaria. 
Tabel 1. Rataan tinggi tanaman, jumlah anakan dan jumlah daun rumput Setaria selama pengamatan

\begin{tabular}{lccc}
\hline Variabel/Parameter & P0 & P1 & P2 \\
\hline Tinggi tanaman (cm) & $35.10 \pm 2.28^{\mathrm{a}}$ & $38.97 \pm 3.06^{\mathrm{b}}$ & $39.10 \pm 2.42^{\mathrm{b}}$ \\
Jumlah daun (helai) & $71.16 \pm 16.44^{\mathrm{a}}$ & $101.47 \pm 16.39^{\mathrm{b}}$ & $101.70 \pm 13.62^{\mathrm{b}}$ \\
Jumlah anakan (anakan) & $13.43 \pm 3.08^{\mathrm{a}}$ & $21.30 \pm 5.98^{\mathrm{b}}$ & $21.23 \pm 4.98^{\mathrm{b}}$ \\
\hline Ketangan: Sup
\end{tabular}

Keterangan: Superskrip yang berbeda pada baris yang sama menunjukkan perbedaan yang nyata $(\mathrm{P}<0,05) . \mathrm{P} 0=\mathrm{Kontrol} /$ tanpa pupuk; $\mathrm{P} 1=$ Kotoran kuskus dari konsumsi pisang; dan $\mathrm{P} 2=$ Kotoran kuskus dari konsumsi avokad.

\subsection{Tinggi Tanaman}

Semakin tinggi suatu tanaman mengindikasikan bahwa pertumbuhannya semakin baik, begitu pula dengan produksinya. Rataan tinggi tanaman Setaria semakin meningkat antara perlakuan kontrol dan perlakuan pupuk kotoran kuskus, dan secara statistik berpengaruh nyata $(\mathrm{P}<0,05)$. Perlakuan P1 dan P2 nyata memberikan pengaruh pertambahan tinggi rumput Setaria sebesar 0,13 $\mathrm{cm}$. Hal ini disebabkan karena pupuk kotoran satwa kuskus dari konsusmi pisang dan avokad yang diberikan mengandung unsur hara yang dibutuhkan oleh tanaman untuk bertumbuh yaitu nitrogen $(\mathrm{N})$, fosfor $(\mathrm{P})$ dan kalium $(\mathrm{K})$. Hasil analisis mineral pupuk kotoran satwa kuskus antara lain: P $0,61 \%, \mathrm{~K} 3,20 \%$ dan $\mathrm{N}$ $0,85 \%$ untuk kotoran dari konsumsi pisang, sedangkan kotoran kuskus dari konsumsi avokad mengandung P 0,12\%, K 2,56 \% dan N 0,76\% (Mauri, 2021). Hartono (2011) menyatakan bahwa penambahan pupuk organik pada tanah akan memperbaiki sifat biologi tanah sehingga akan menunjang pertumbuhan dan perkembangan tanaman. Hasil ini lebih rendah dibandingkan dengan Suningsih, Noprida, \& Feriyanto (2019) yaitu $69,75 \mathrm{~cm}$ dengan dosis pemberian $100 \mathrm{~g} /$ polybag pupuk organik kotoran kambing. Jumlah dosis pupuk organik diberikan berbeda pula sehingga memberikan respon yang berbeda.

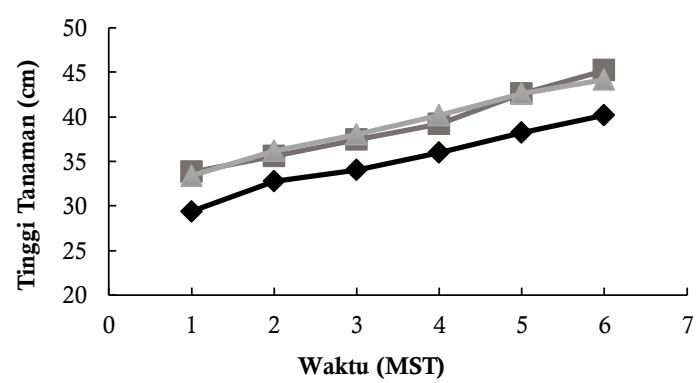

Gambar 1. Laju pertumbuhan tinggi tanaman rumput Setaria per minggu. $\rightarrow \mathrm{P} 0=$ kontrol (tanpa pupuk); $-\mathrm{P} 1=$ pupuk kotoran kuskus dari konsumsi pisang; $\rightarrow \mathrm{P} 2=$ pupuk kotoran kuskus dari konsumsi avokad. MST $=$ Minggu setelah tanam
Laju pertumbuhan tinggi tanaman (Gambar 1) meningkat seiring dengan pertambahan waktu atau umur tanaman Setaria. Peningkatan ini terjadi karena dosis pupuk organik yang diberikan mampu diserap dengan baik oleh rumput Setaria sehingga pertumbuhan terus meningkat seiring dengan berjalannya waktu. Hal ini sejalan dengan pendapat Rini (2011), bahwa pupuk organik dapat merangsang pertumbuhan akar, batang, dan daun pada tanaman. Salah satu unsur hara yang dimanfaatkan tanaman adalah nitrogen (N) (Hadisuwito, 2012).

Uji lanjut Duncan menunjukkan bahwa perlakuan $\mathrm{P0}$ berbeda nyata dengan perlakuan P1 dan P2, namun pada perlakuan P1 dan P2 tidak berbeda nyata terhadap pertumbuhan tinggi tanaman. Hal ini disebabkan karena antara kontrol dan perlakuan terjadi perbedaan unsur hara sedangkan pada perlakuan P1 dan P2, jumlah hara yang ditambahkan atau diperoleh masing-masing tanaman cenderung sama akibat dosis pupuk kotoran kuskus yang diberikan juga sama yaitu sebanyak $40 \mathrm{~g}$ /polybag. $\mathrm{N}$ kotoran kuskus dari konsumsi pisang yaitu $0,85 \%$ dan dari avokad 0,76 \% (Mauri, 2021), mampu berakumulasi dengan tanah untuk menunjang proses fotosintesis pada tanaman Setaria (Muhakka, Napoleon, \& Isti'adah, 2013). Hal ini sesuai dengan pendapat Lakitan (2007) bahwa pertambahan tinggi tanaman merupakan proses fisiologi dimana sel melakukan pembelahan. Pada proses pembelahan tersebut tanaman memerlukan unsur hara esensial dalam jumlah yang cukup yang diserap tanaman melalui akar. Hartono (2011) menyatakan bahwa tanaman akan tumbuh secara optimal jika ditanam pada tempat yang memenuhi syarat tumbuhnya seperti faktor lingkungan yaitu faktor iklim dan sifat tanah seperti: $\mathrm{pH}$ tanah, ketersediaan unsur hara, volume pupuk yang diberikan. Hal ini ditunjang dengan data iklim BMKG Manokwari (2020) bahwa jumlah rata-rata suhu udara 27,5 ${ }^{\circ} \mathrm{C}$; kelembaban udara 81,3 \%; lama penyinaran matahari $57 \%$; curah hujan 348,6 \% dan jumlah hari hujan 21,3\% (19 hari). Iklim ini sudah sesuai 
dengan data iklim yang ideal bagi tanaman atau rumput yaitu $26-28^{\circ} \mathrm{C}$ (Suningsih et al., 2019).

\subsection{Jumlah Daun (Helai)}

Tabel 1 menunjukkan bahwa rataan jumlah daun mencapai 102 helai daun pada perlakuan P2 yaitu perlakuan kotoran kuskus dengan konsumsi avokad, perlakuan P1 yaitu perlakuan kotoran kuskus dengan konsumsi pisang sebanyak 101,47 helai daun dan paling rendah pada perlakuan P0 atau kontrol yaitu 71,16 helai daun per polybag. Hal ini terjadi karena unsur hara pada perlakuan P2 dan P1 mampu berakumulasi dengan tanah (media tanam) sehingga membantu dalam menunjang proses fotosintesis pada tanaman Setaria dengan pembentukan jumlah daun. $\mathrm{N}$ kotoran kuskus dari konsumsi pisang yaitu 0,85 \% dan dari avokad 0,76 \% (Mauri, 2021), mampu berakumulasi dengan tanah untuk menunjang proses fotosintesis pada tanaman Setaria (Muhakka et al., 2013). Hasil analisis statistik (Anova) menunjukkan bahwa perlakuan penambahan pupuk organik kotoran kuskus P1 dan $\mathrm{P} 2$ memberikan pengaruh nyata $(\mathrm{P}<0,05)$ terhadap jumlah daun. Hasil penelitian ini lebih tinggi jika dibandingkan dengan penelitian Sahlan, Suarna, \& Roni (2018) yaitu 92 helai daun rumput Setaria dengan dosis penggunaan pupuk organik kotoran kuda sebesar $40 \mathrm{~g} /$ pot. Hal ini diduga bahwa kandungan unsur hara pupuk organik kotoran kuskus berupa nitrogen $(\mathrm{N})$, fosfor $(\mathrm{P})$ dan kalium $(\mathrm{K})$ lebih tinggi dibandingkan dengan kandungan unsur hara pada pupuk organik kotoran kuda atau kotoran hewan lainnya.

Penggunaan pupuk organik kotoran kuskus pada perlakuan P1 dan P2 mampu membantu menambah dan meningkatkan penyerapan unsur hara di dalam tanah pada polybag sehingga memberikan respon jumlah daun yang berbeda dengan kontrol. Selain itu, dapat dikatakan bahwa proses fotosintesis dapat berjalan dengan baik sebagaimana idealnya terjadi pada suatu tanaman. Sejalan dengan Ifradi et al. (2012), yang mengemukakan bahwa semakin banyak unsur hara yang terserap oleh tanaman maka proses fotosintesis akan semakin meningkat sehingga makin banyak pula karbohidrat yang dihasilkan oleh tanaman yang akan membantu pembentukan batang dan daun tanaman. Darmawan, Herlina, \& Soelistyono (2013) menyatakan bahwa $\mathrm{N}$ yang tinggi pada pupuk organik mampu menunjang proses pembentukan daun tanaman karena $\mathrm{N}$ merupakan bahan dasar penyusun asam amino dan protein. Hasil ini sejalan dengan laju pertambahan jumlah daun Setaria (Gambar 2).

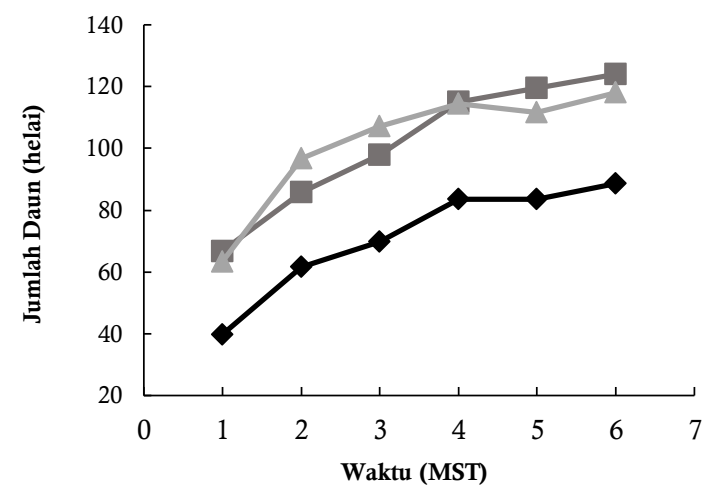

Gambar 2. Laju pertambahan jumlah daun rumput Setaria per minggu. $\rightarrow \mathrm{P} 0=\operatorname{kontrol}($ tanpa pupuk); $-\mathrm{P} 1=$ pupuk kotoran kuskus dari konsumsi pisang; $\rightarrow \mathrm{P} 2=$ pupuk kotoran kuskus dari konsumsi avokad. MST $=$ Minggu setelah tanam

Laju pertambahan jumlah daun juga meningkat seiring dengan bertambahnya waktu sesuai dengan perlakuan pupuk kotoran kuskus yang diberikan, P1 dan P2 nyata lebih tinggi daripada P0. Pemberian pupuk kotoran kuskus diharapkan sudah terurai secara sempurna sehingga penyerapan unsur hara oleh tanaman sudah cukup maksimal untuk merespon pertumbuhan dan meningkatkan perkembangan pada jumlah daun. Pemenuhan kebutuhan $\mathrm{N}$ pada tanaman akan menyebabkan terjadinya keseimbangan rasio antara akar dan daun, sehingga pertumbuhan vegetatif akan berjalan sempurna (Supartha, Wijana, \& Adnyana, 2012). Berdasarkan fungsinya pada tanaman, daun juga berhubungan dengan proses fotosintesis, sebagai tempat terjadinya proses ini karena mengandung klorofil atau zat hijau daun (Salisbury \& Ross, 1995; Sawen, 2012; Sawen \& Nuhuyanan, 2020). Unsur $\mathrm{N}$, P, dan $\mathrm{K}$ berperan penting dalam proses fotosintesis untuk menghasilkan fotosintat dan meningkatkan pertumbuhan tanaman melalui metabolisme penyerapan unsur-unsur hara ini menjadi energi atau senyawa organik (Firmansyah, Syakir, \& Lukman, 2017; Kolo \& Sio, 2020; Tresia \& Saenab, 2020). Situmeang (2020) menyatakan bahwa peningkatan jumlah daun dan luas daun akan meningkatkan laju pertumbuhan tanaman karena asimilat yang terbentuk sebagai produk fotosintesis akan dimanfaatkan untuk membentuk sel-sel yang baru pada organ-organ vegetatif. Hal ini sesuai dengan hasil penelitian yang dilakukan oleh Tresia \& Saenab (2020) yang memberikan kotoran kelinci sebagai pupuk organik untuk mengetahui respon pertumbuhan Indigofera, yang hasilnya ditemukan bahwa jumlah daun 
semakin meningkat dengan cepat pada laju pertumbuhan daun pada umur 7 minggu ke umur 11 minggu. Semakin banyak jumlah daun, kualitas hijauan pakan semakin baik, karena daun memiliki kandungan gizi lebih baik daripada bagian batang (Ekawati, 2017). Hasil ini sejalan juga dengan pertumbuhan tinggi tanaman Setaria yang dihasilkan sebelumnya.

\subsection{Jumlah}

Hasil analisis statistik menunjukkan bahwa pupuk organik kotoran kuskus memberikan pengaruh nyata $(\mathrm{P}<0,05)$ terhadap jumlah anakan yang dihasilkan. Rataan jumlah anakan tertinggi yaitu P1 dan P2 (21 anakan) dan terendah pada perlakuan P0 (13 anakan). Hasil penelitian ini lebih tinggi dibanding dengan yang diteliti oleh Korejang, Anis, Kaunang, \& Sumolang (2019) yaitu 17,13 anakan rumput Setaria dengan perlakuan pupuk organik bokasi kotoran ayam 20 ton/ha. Hal ini karena pupuk kotoran kuskus yang diberikan pada media tanam telah dimanfaatkan oleh tanaman untuk memenuhi kebutuhan unsur hara sehingga dapat meningkatkan jumlah anakan. Pupuk organik yang berasal dari pupuk kandang mengandung sejumlah unsur hara dan bahan organik yang dapat memperbaiki sifat fisik, kimia dan biologi tanah serta menyediakan unsur hara $\mathrm{N}, \mathrm{P}$ dan $\mathrm{K}$ yang dibutuhkan oleh tanaman. Hal ini sependapat dengan Muhakka et al. (2013), bahwa bila ruang tumbuh tanaman dan unsur hara cukup tersedia dalam tanah sesuai dengan kebutuhan tanaman maka akan semakin banyak terbentuk individu baru.

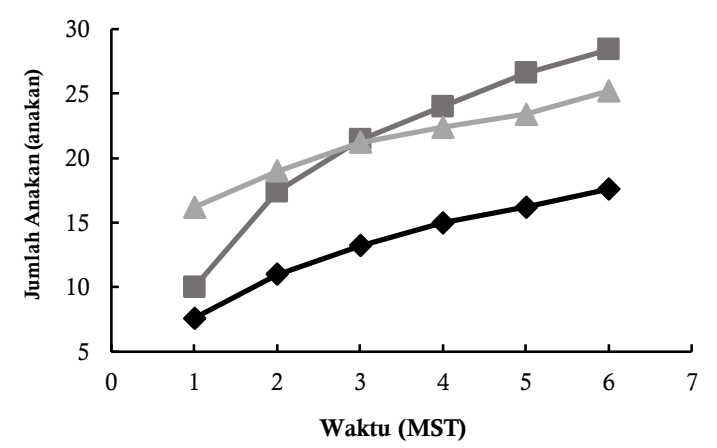

Gambar 3. Laju pertambahan jumlah anakan rumput Setaria per minggu. $\rightarrow \mathrm{P} 0=\operatorname{kontrol}($ tanpa pupuk); $\rightarrow \mathrm{P} 1=$ pupuk kotoran kuskus dari konsumsi pisang; $-\mathrm{P} 2=$ pupuk kotoran kuskus dari konsumsi avokad. MST $=$ Minggu setelah tanam .

Hasill uji lanjut Duncan menunjukkan bahwa perlakuan P0 berbeda nyata dengan perlakuan P1 dan P2 tetapi kedua perlakuan P1 dan P2 tidak berbeda nyata. Hal ini karena pupuk organik kotoran kuskus memberikan pengaruh langsung terhadap fisiologi tanaman sehingga dapat meningkatkan pertumbuhan rumput Setaria salah satunya yaitu pertambahan jumlah anakan. Hal ini ditunjang pendapat Lakitan (2007) yang menyatakan bahwa pemberian pupuk kandang pada rumput akan memperbaiki struktur tanah sehingga meningkatkan pertumbuhan akar tanaman dari pori-pori tanah sehingga memudahkan tunastunas baru tumbuh menembus permukaan tanah. Laju pertambahan jumlah anakan per minggu dapat dilihat pada Gambar 3.

Secara grafis, jumlah anakan meningkat sesuai dengan perlakuan pupuk kotoran kuskus dan umur tanaman. Berdasarkan hasil analisis pupuk kotoran kuskus mengandung unsur hara $\mathrm{N}=0,86 \%, \mathrm{Ca}=0.61 \%, \mathrm{P}=0,47 \%$ dan $\mathrm{K}=$ $3,20 \%$ untuk kotoran berbasis pakan pisang, sedangkan untuk pakan berbasis avokad, kotoran kuskus mengandung hara $\mathrm{N}=0,76 \%, \mathrm{Ca}=0,22$ $\%, \mathrm{P}=0,12 \%$ dan $\mathrm{K}=2,56 \%$ (Mauri, 2021). Hasil ini memberikan indikasi bahwa kotoran kuskus juga merupakan pupuk organik yang baik karena mengandung unsur hara yang dibutuhkan tanaman. Purbajanti (2013) mengemukakan bahwa pupuk kandang mempunyai pengaruh yang baik terhadap sifat fisik dan kimia tanah sehingga ikut menyuplai perkembangan mikroba tanah. Pertambahan jumlah anakan rumput Setaria yang dihasilkan ditunjang oleh hasil C/N yang dihasilkan yaitu untuk perlakuan kontrol (P0) sebesar 12, perlakuan P1 dan P2 masingmasing menghasilkan $\mathrm{C} / \mathrm{N}$ yang sama yaitu 13 (Mauri, 2021). Hasil ini sedikit lebih tinggi dibandingkan dengan Suningsih et al. (2019) yaitu jumlah anakan rumput Setaria yang diberikan pupuk kotoran kambing sebesar 300 g/polybag adalah 20,42 anakan. Hal ini karena pupuk organik asal kotoran ternak juga mampu memberikan pengaruh langsung terhadap proses fisiologis tanaman sehingga dapat meningkatkan pertumbuhan rumput Setaria seperti mengokohkan akar tanaman, pertambuhan lebar atau luas daun yang juga meningkat termasuk batang dan jumlah anakan (Niknik et al., 2014). Hasil yang sama juga ditunjukkan oleh parameter tinggi tanaman dan jumlah daun rumput Setaria yaitu pemberian pupuk organik kotoran kuskus dapat meningkatkan pertumbuhan tanaman (Situmeang, 2020).

\section{Kesimpulan}

Pemberian pupuk kotoran kuskus dengan konsumsi pisang (P1) dan avokad (P2) dengan dosis $40 \mathrm{~g} /$ polybag mampu memberikan peningkatan pertumbuhan pada rumput Setaria, 
dengan demikian kotoran kuskus berpotensi sebagai pupuk organik.

\section{Daftar Pustaka}

BMKG Manokwari. (2020). Laporan Data Ilkim bulan Januari-April 2020. Manokwari. Retrieved from https://www.bmkg.go.id /cuaca/prakiraan-cuaca.bmkg?Kota= Manokwari\&AreaID $=501467 \&$ Prov $=35$

Darmawan, A. F., Herlina, N., \& Soelistyono, R. (2013). Pengaruh berbagai macam bahan organik dan pemberian air terhadap pertumbuhan dan hasil tanaman Sawi (Brassica juncea L.). Jurnal Produksi Tanaman, 1(5), 389-397.

Ekawati, R. (2017). Pertumbuhan dan produksi pucuk kolesom pada intensitas cahaya rendah. Jurnal Kultivasi, 16(3), 412-417. https://doi.org/10.24198/kultivasi.v16i3. 13719

Firmansyah, I., Syakir, M., \& Lukman, L. (2017). Pengaruh kombinasi dosis pupuk $\mathrm{N}$, $\mathrm{P}$, dan $\mathrm{K}$ terhadap pertumbuhan dan hasil tanaman terung (Solanum melongena L.). Jurnal Hortikultura, 27(1), 69-78. https://doi.org/10.21082/jhort.v27n1.201 7.p69-78

Hadisuwito, S. (2012). Membuat Pupuk Organik Cair (N. Opi \& P. Rahmat, Eds.). Jakarta Selatan: PT. AgroMedia Pustaka.

Hartono, B. (2011). Produksi dan kandungan nutrisi rumput Setaria (Setaria sphacelata) pada pemotongan pertama yang diberi pupuk kandang feses kambing dengan dosis berbeda. Universitas Islam Negeri Sultan Sarif Kasim Riau.

Ifradi, Evitayani, Fariani, A., Warly, L., Suyitman, Yani, S., \& Emikasmira. (2012). Pengaruh dosis pupuk N, P, dan K terhadap kecernaan secara in vitro rumput gajah (Pennisetum purpureum) cv. Taiwan yang di inokulasi CMA Glomus manihotis pada lahan bekas tambang batubara. Jurnal Peternakan Indonesia, 14(1), 279-285. https: //doi.org/10.25077/jpi.14.1.279-285.2012

Irfan, Rasdiansyah, \& Munadi, M. (2017). Kualitas bokashi dari kotoran berbagai jenis hewan. Jurnal Teknologi dan Industri Pertanian Indonesia, 09(01), 24-27. https: //doi.org/10.17969/jtipi.v9i1.5976

Kolo, M. I., \& Sio, S. (2020). Pengaruh pemberian pupuk kompos terhadap pertumbuhan rumput Setaria (Setaria sphacelata. S). JAS: Journal of Animal Science, 5(3), 48-50. https://doi.org/10.32938/ja. v5i3.898

Korejang, M., Anis, S. D., Kaunang, W. B., \& Sumolang, C. I. J. (2019). Respon pertumbuhan rumput Brachiaria humidicola cv Tully dengan pemberian pupuk organik bokashi kotoran ayam petelur. Zootec, 39(1), 33-41. https://doi. org/10.35792/ zot.39.1.2019.22120

Lakitan, B. (2007). Dasar-dasar Fisiologi Tumbuhan. Jakarta: PT Raja Grafindo Persada.

Mauri, F. R. S. (2021). Respon pertumbuhan dan serapan nitrogen rumput Setaria (Setaria sphacelata) berbasis pupuk organik feses Kuskus.Fakultas Peternakan, Universitas Papua.

Muhakka, Napoleon, A., \& Isti'adah, H. (2013). Pengaruh pemberian asap cair terhadap pertumbuhan rumput Raja (Pennisetum purpureophoides). Pastura: Journal of Tropical Forage Science, 3(1), 30-34. https://doi.org/ 10.24843/Pastura.2013.v03.i01.p08

Niknik, Marzuki, A., \& Sugiyanto, B. (2014). Pemberian pupuk organik ayam petelur dan konsentrasi EM4 dalam meningkatkan produksi rumput Setaria (Setaria sphacelata). Jurnal Ilmiah INOVASI, 14(1), 65-74. https: //doi.org/10.25047/jii.v14i1.55

Prawiradiputra, B. R., Sajimin, N. D., \& Purwantari, I. H. (2006). Hijauan Pakan Ternak di Indonesia. Jakarta: Badan Penelitian dan Pengembangan Pertanian.

Purbajanti, E. D. (2013). Rumput dan Legum sebagai Hijauan Makanan Ternak. Yogyakarta: Graha Ilmu.

Rini, A. (2011). Cara Membuat Pupuk Organik untuk Tanaman Buah dan Bunga yang Ramah Lingkungan. Jakarta: Pustaka Mina.

Sahlan, M., Suarna, I. W., \& Roni, N. G. K. (2018). Pengaruh berbagai jenis pupuk organik terhadap produktivitas rumput Panicum maximum, Setaria splendida, dan Pennisetum purpureum. Pastura: Journal of Tropical Forage Science, 8(1), 13-19.

Salisbury, F. B., \& Ross, C. W. (1995). Fisiologi Tumbuhan (3rd ed., Vol. 343). Bandung: ITB Bandung.

Sawen, D. (2012). Pertumbuhan rumput Gajah (Pennisetum purpureum) dan Benggala (Panicum maximum) akibat perbedaan 
intensitas cahaya. Agrinimal: Jurnal Ilmu Ternak dan Tanaman, 2(1), 17-20.

Sawen, D., \& Nuhuyanan, L. (2020). Respon pertumbuhan Rumput Gajah (Pennisetum purpureum), Setaria (Setaria spacelata) dan Benggala (Panicum maximum) terhadap perbedaan salinitas. Pastura: Journal of Tropical Forage Science, 10(1), 13-17.

Sawen, D., \& Sinery, A. S. (2020). The feed plants species of Cuscus Phalanger orientalis in Yamna Island, Sarmi Regency. World Journal of Advanced Research and Reviews, 6(1), 031-039. https://doi.org/10. 30574/wjarr.2020.6.1.0043

Situmeang, Y. P. (2020). Biochar Bambu Perbaiki Kualitas Tanah dan Hasil Jagung. In Y. P. Situmeang (Ed.). Surabaya: Scopindo Media Pustaka.

Steel, R. G. D., \& Torrie, J. H. (1993). Prinsip dan prosedur statistika (pendekatan biometrik). Jakarta: Gramedia Pustaka Utama.

Suningsih, N., Noprida, H., \& Feriyanto. (2019). Pertumbuhan dan produksi rumput Setaria (Setaria splendida Stapf) sebagai pakan ternak ruminansia pada tanah ultisol dengan penambahan pupuk kotoran kambing. In S. Herlinda (Ed.), Seminar Nasional Lahan Suboptimal 2019: Smart farming yang Berwawasan Lingkungan untuk Kesejahteraan Petani (pp. 201-210). Palembang: Unsri Press.

Supartha, I. N. Y., Wijana, G., \& Adnyana, G. M. (2012). Aplikasi jenis pupuk organik pada tanaman padi sistem pertanian organik. E-Jurnal Agroekoteknologi Tropika, 1(2), 98-106.

Tresia, G. E., \& Saenab, A. (2020). Respon pertumbuhan Indigofera (Indigofera zollingeriana) yang diberikan pupuk kotoran kelinci dan biochar. Jurnal Sains Dan Teknologi Peternakan, 2(1), 19-26. https:// doi.org/10.31605/jstp.v2i1.840 